\section{Regards sur l'économie allemande}

Bulletin économique du CIRAC

$95 \mid 2010$

Varia

\title{
Économie de marché
}

BERGER Johannes, Der diskrete Charme des Marktes. Zur sozialen

Problematik der Marktwirtschaft

\section{(2) OpenEdition}

Journals

Édition électronique

URL : http://journals.openedition.org/rea/4053

DOI : $10.4000 /$ rea.4053

ISBN : 978-2-8218-0886-7

ISSN : 1965-0787

Éditeur

CIRAC

Édition imprimée

Date de publication : 1 mars 2010

ISSN : 1156-8992

Référence électronique

"Économie de marché », Regards sur l'économie allemande [En ligne], 95 | mars 2010, mis en ligne le 08 mars 2010, consulté le 22 septembre 2020. URL : http://journals.openedition.org/rea/4053 ; DOI : https://doi.org/10.4000/rea.4053

Ce document a été généré automatiquement le 22 septembre 2020

(C) CIRAC 


\section{Économie de marché}

BERGER Johannes, Der diskrete Charme des Marktes. Zur sozialen Problematik der Marktwirtschaft

\section{RÉFÉRENCE}

BERGER Johannes, Der diskrete Charme des Marktes. Zur sozialen Problematik der Marktwirtschaft, VS Verlag für Sozialwissenschaften, Wiesbaden, 2009, 240 p.

1 Le marché est incompatible avec la solidarité, pensent la plupart des sociologues allemands. Mais pas l'auteur de cet ouvrage (professeur émérite de l'Université de Mannheim), un des rares d'entre eux à porter considération aux sciences économiques. Il y décline sous toutes leurs facettes les approches de l'égalité, ou plutôt - pour mieux rendre l'équilibre cherché par la doctrine de l'économie sociale de marché : de l'équité. (ib) 